\title{
Effects of Chandra Nadi Pranayama on Hematological Parameters
}

\author{
Baljinder Singh Bal \\ Department of Physical Education ( $T$ ), Guru Nanak Dev University, Amritsar, India \\ Email: bal baljindersingh@yahoo.co.in
}

Received 8 January 2015; accepted 8 May 2015; published 13 May 2015

Copyright (C) 2015 by author and Scientific Research Publishing Inc.

This work is licensed under the Creative Commons Attribution International License (CC BY). http://creativecommons.org/licenses/by/4.0/

c) (i) Open Access

\begin{abstract}
Study Aim: To assess the effects of Chandra nadi pranayama on hematological parameters. Methods: Thirty, university level girls of Department of Physical Education (T), Guru Nanak Dev University, Amritsar between the age group of $21-26$ years (Mean \pm SD: age $22.8 \pm 2.023$ yrs, height $5.53 \pm 1.822 \mathrm{ft}$, body mass $61.506 \pm 4.514 \mathrm{~kg}$ ) volunteered to participate in the study. The subjects from Group-A: experimental were subjected to a 4-week Chandra nadi pranayama (Left Nostril). Statistical Analysis: Student t test for paired samples was utilized to compare the means of the pretest and the post-test. Results: No significant differences were found in Hemoglobin (Hb), Total Cholesterol (TC), Low Density Lipoprotein Cholesterol (LDL-Cholesterol), High Density Lipoprotein Cholesterol (HDL-Cholesterol) and Triglycerides (TG) among university level girls.
\end{abstract}

\section{Keywords}

Chandra Nadi Pranayama, Hemoglobin, Total Cholesterol, Low Density Lipoprotein Cholesterol, High Density Lipoprotein Cholesterol, Triglycerides

\section{Introduction}

Yoga — a way of life_-is marked with certain qualities namely balance, health, harmony, and bliss Nagendra \& Nagarathna (1977). Inflating the matter into wider semantic denominations, Meditation-being part of yoga, which is the seventh limb of Ashtanga Yoga Tamini (1961), is a state of alert rest as stated by Maharishi Mahesh Yogi (1972), who founded a new technique of meditation, popularly known as transcendental meditation. By Yogic participation, a person is supposed to reach a state of mental composure, where responses to favorable or unfavorable external events are well under the individual's control, and responses are moderate in intensity Telles et al. (2000). The science of yoga is a powerful stream of knowledge, which enables the practitioners to achieve radiant physical health, serene mind, continues spiritual uplift, and creates the ability for harmonious 
social living Kumar (2005). The traditional yogic practices of pranayama have a history of over 4000 years. The practice of pranayama has substantiated valuable both for the healthy and for the sick. In addition, recent research has established the therapeutic effect on some diseases. Women subject to psychological stress found significant improvement of their symptoms after a three-month yoga program Michalsen et al. (2005). In anxiety disorders, at least two comparative studies of yoga and meditation techniques (mindfulness) revealed the same effectiveness for both procedures (Krisanaprakornkit et al., 2006 \& Smith et al., 2007). There are a multitude of pranayama techniques and it is traditionally taught that each of them has different psycho-physiological benefits Gitananda (2008). Pranayama has immense therapeutic potential in a wide range of psychosomatic disorders, but there is currently lack of an adequate meta-analysis in relation to Chandra nadi pranayama to assess its efficacy with respect to hematological parameters and as a result the present study was conducted to find out effects of Chandra nadi pranayama on hematological parameters.

\section{Methods}

\subsection{Subjects}

Thirty, university level girls of Department of Physical Education (T), Guru Nanak Dev University, Amritsar between the age group of $21-26$ years (Mean \pm SD: age $22.8 \pm 2.023$ yrs, height $5.53 \pm 1.822 \mathrm{ft}$, body mass $61.506 \pm 4.514 \mathrm{~kg}$ ) volunteered to participate in the study. The subjects were purposively assigned into two groups:

- Group-A: Experimental $\left(\mathrm{n}_{1}=15\right)$;

- Group-B: Control $\left(\mathrm{n}_{2}=15\right)$.

All the subjects were informed about the objective and protocol of the study. Distribution and demographics of subjects are brought forth in Table 1.

\subsection{Procedure}

This study is designed as a retrospective cross-sectional study (Figure 1). The subjects from Group-A: Experimental were subjected to a 4-weeks Chandra nadi pranayama (Left Nostril). This lasted 3 weeks and consisted of daily sessions as shown in Table 2 \& Figure 2. Hemoglobin was determined in the blood samples of all the subjects with the use of a hematology analyzer (Celldyne model 3500$)$. Blood samples (10 ml) for the determi-

Table 1. Distribution and demographics of subjects.

\begin{tabular}{cccc}
\hline & \multicolumn{3}{c}{ Sample Size $(\mathbf{N}=\mathbf{3 0})$} \\
Variables & Total $(\mathbf{N}=\mathbf{3 0})$ & Experimental group $\left(\mathbf{n}_{\mathbf{1}}=\mathbf{1 5}\right)$ & Control group $\left(\mathbf{n}_{\mathbf{2}}=\mathbf{1 5}\right)$ \\
\hline Age & $22.8 \pm 2.023$ & $22.6 \pm 1.956$ & $23 \pm 2.138$ \\
Body Height & $5.53 \pm 1.822$ & $5.546 \pm 1.959$ & $5.513 \pm 1.726$ \\
Body Mass & $61.506 \pm 4.514$ & $61.92 \pm 4.866$ & $61.093 \pm 4.262$ \\
\hline
\end{tabular}

Table 2. Experimental treatment.

\begin{tabular}{|c|c|c|c|}
\hline \multicolumn{4}{|c|}{ 4-Weeks Chandra Nadi Pranayama Training } \\
\hline Weeks & Schedule & Time & Duration \\
\hline \multirow{3}{*}{$\mathrm{I}^{\text {st }}$ Week } & Preliminary Yogic Exercises & 5 Minute & \\
\hline & Practice of Chandra Nadi Pranayama (9 Rounds $\times 1$ Set) & 10 Minute & 20 Minute \\
\hline & Relaxation Posture & 5 Minute & \\
\hline \multirow{3}{*}{$2^{\text {nd }}$ Week } & Preliminary Yogic Exercises & 5 Minute & \\
\hline & Practice of Chandra Nadi Pranayama (9 Rounds $\times 2$ Set) & 15 Minute & 25 Minute \\
\hline & Relaxation Posture & 5 Minute & \\
\hline \multirow{3}{*}{$3^{\text {rd }}$ Week } & Preliminary Yogic Exercises & 5 Minute & \\
\hline & Practice of Chandra Nadi Pranayama (9 Rounds $\times 3$ Set) & 20 Minute & 30 Minute \\
\hline & Relaxation Posture & 5 Minute & \\
\hline \multirow{3}{*}{$4^{\text {rd }}$ Week } & Preliminary Yogic Exercises & 5 Minute & \\
\hline & Practice of Chandra Nadi Pranayama (9 Rounds $\times 4$ Set) & 25 Minute & 35 Minute \\
\hline & Relaxation Posture & 5 Minute & \\
\hline
\end{tabular}




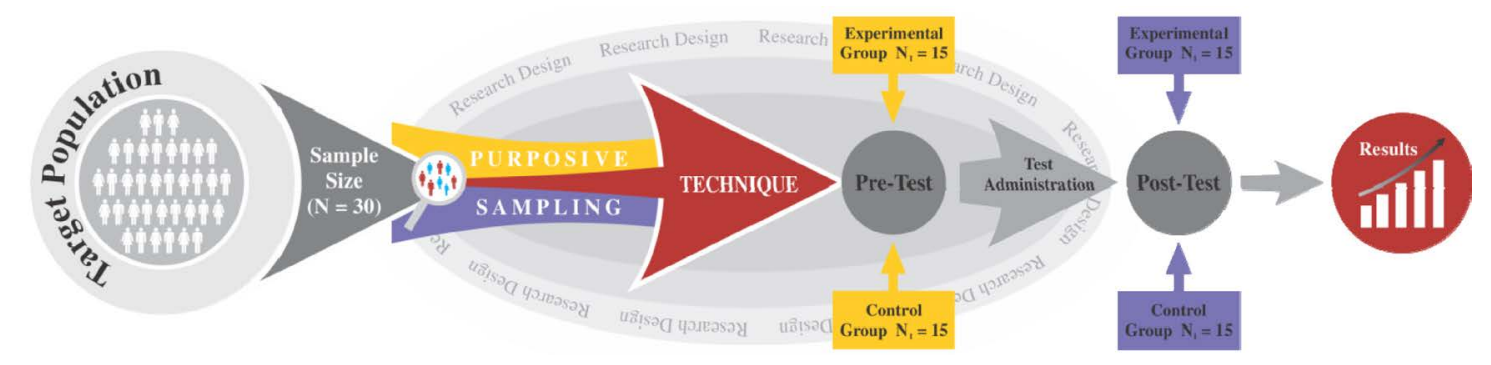

Figure 1. Study design.

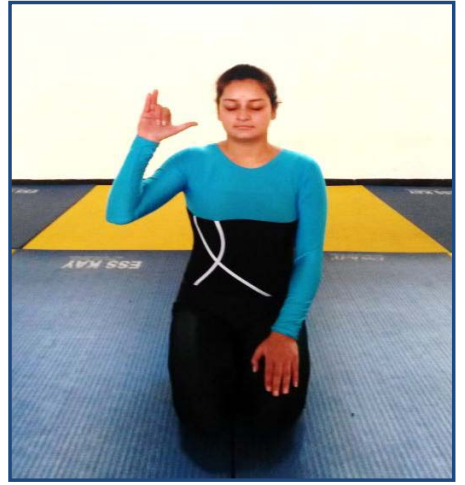

(a)

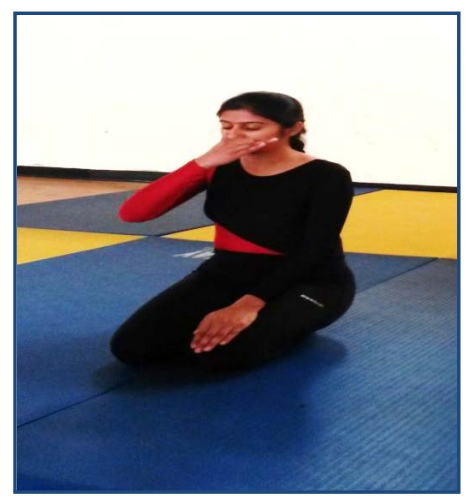

(c)

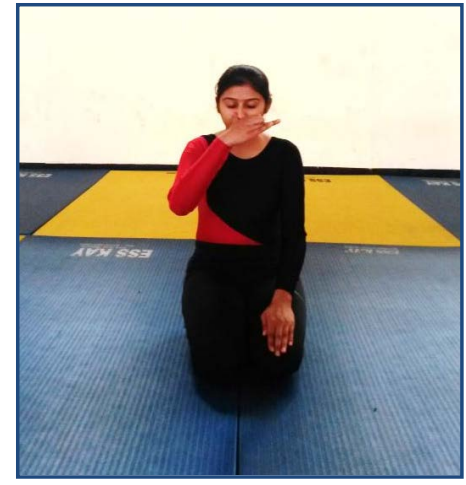

(b)

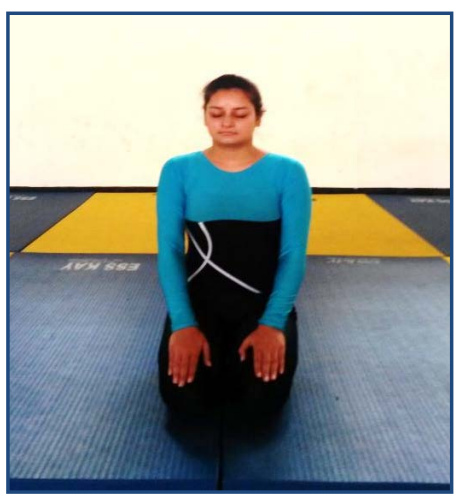

(d)

Figure 2. Subject performing Chandra Nadi Pranayama.

nation of lipid profiles were obtained. All of biochemical tests have been done with serum samples. Lipid parameters (Triglyceride; Cholesterol; Low-density lipoprotein; High-density lipoprotein) were measured using Boehringer Mannheim kits and Clinilab, BioMerieux analyser as used by Jastrzebska et al. (2002). The Collection of Biochemical tests with Serum Samples show in the Figure 3.

\section{Statistical Analysis}

Statistical analyses were performed using the Statistical Package for the Social Sciences for Windows version 16.0 software (SPSS Inc., Chicago, IL). Data is expressed as the mean \pm SD. Student $t$ test for paired samples was utilized to compare the means of the pre-test and the post-test. The level of significance was set at 0.05 .

\section{Results}

\subsection{Hemoglobin ( $\mathrm{Hb}$ )}

The results of Hematological Parameter in group (Experimental) and group (Control) are shown in Table 3. The 


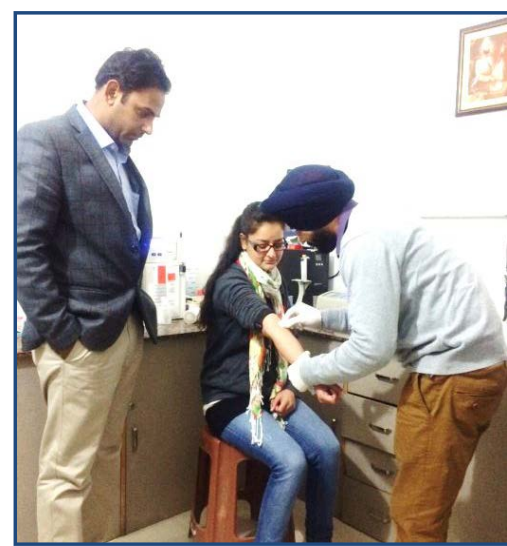

(a)

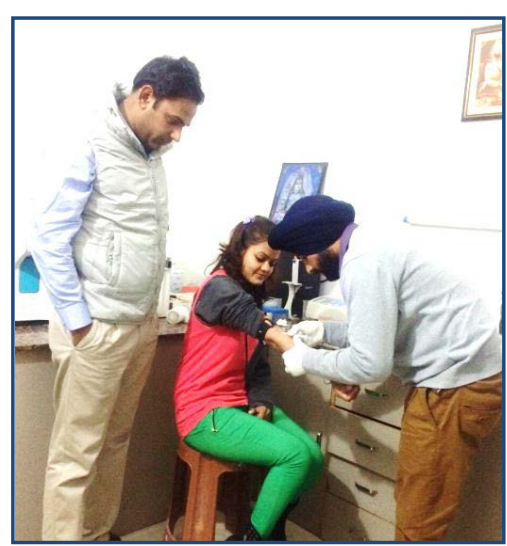

(b)

Figure 3. Biochemical tests with Serum Samples.

Table 3. Descriptive statistics (Mean \& Standard Deviation) and paired sample t-test of hematological parameter (i.e., Hemoglobin (Hb), total cholesterol (TC), low density lipoprotein cholesterol (LDL-cholesterol), high density lipoprotein cholesterol (HDL-cholesterol) and triglycerides (TG) of university level girls.

\begin{tabular}{|c|c|c|c|c|c|c|}
\hline \multicolumn{7}{|c|}{ Hemoglobin (Hb) } \\
\hline Group & Number & Mean & $\begin{array}{l}\text { Standard } \\
\text { Deviation }\end{array}$ & $\begin{array}{l}\text { Standard } \\
\text { Error } \\
\text { of the } \\
\text { Mean }\end{array}$ & t-value & $p$-value \\
\hline $\begin{array}{c}\text { Experiment (Pre-test) } \\
\text { Experimental (Post-test) }\end{array}$ & $\begin{array}{l}15 \\
15\end{array}$ & $\begin{array}{l}12.780 \\
12.913\end{array}$ & $\begin{array}{l}0.421 \\
0.456\end{array}$ & $\begin{array}{l}0.108 \\
0.117\end{array}$ & 1.740 & 0.1038 \\
\hline $\begin{array}{l}\text { Control (Pre-test) } \\
\text { Control (Post-test) }\end{array}$ & $\begin{array}{l}15 \\
15\end{array}$ & $\begin{array}{l}12.473 \\
12.506\end{array}$ & $\begin{array}{l}0.240 \\
0.265\end{array}$ & $\begin{array}{l}0.062 \\
0.068\end{array}$ & 0.517 & 0.6132 \\
\hline \multicolumn{7}{|c|}{ Total Cholesterol (TC) } \\
\hline $\begin{array}{c}\text { Experiment (Pre-test) } \\
\text { Experimental (Post-test) }\end{array}$ & $\begin{array}{l}15 \\
15\end{array}$ & $\begin{array}{l}167.240 \\
168.940\end{array}$ & $\begin{array}{l}14.598 \\
15.355\end{array}$ & $\begin{array}{c}3.7694 \\
3.964\end{array}$ & 1.937 & 0.0732 \\
\hline $\begin{array}{l}\text { Control (Pre-test) } \\
\text { Control (Post-test) }\end{array}$ & $\begin{array}{l}15 \\
15\end{array}$ & $\begin{array}{l}166.760 \\
166.893\end{array}$ & $\begin{array}{l}14.613 \\
14.266\end{array}$ & $\begin{array}{l}3.773 \\
3.683\end{array}$ & 0.581 & 0.5705 \\
\hline \multicolumn{7}{|c|}{ Low Density Lipoprotein Cholesterol (LDL-Cholesterol) } \\
\hline $\begin{array}{c}\text { Experiment (Pre-test) } \\
\text { Experimental (Post-test) }\end{array}$ & $\begin{array}{l}15 \\
15\end{array}$ & $\begin{array}{l}119.120 \\
119.486\end{array}$ & $\begin{array}{l}7.640 \\
7.694\end{array}$ & $\begin{array}{l}1.972 \\
1.986\end{array}$ & 1.243 & 0.2343 \\
\hline $\begin{array}{l}\text { Control (Pre-test) } \\
\text { Control (Post-test) }\end{array}$ & $\begin{array}{l}15 \\
15\end{array}$ & $\begin{array}{l}118.980 \\
119.040\end{array}$ & $\begin{array}{l}7.506 \\
7.532\end{array}$ & $\begin{array}{l}1.938 \\
1.945\end{array}$ & 0.169 & 0.8682 \\
\hline \multicolumn{7}{|c|}{ High Density Lipoprotein Cholesterol (HDL-Cholesterol) } \\
\hline $\begin{array}{c}\text { Experiment (Pre-test) } \\
\text { Experimental (Post-test) }\end{array}$ & $\begin{array}{l}15 \\
15\end{array}$ & $\begin{array}{l}75.120 \\
75.206\end{array}$ & $\begin{array}{l}4.443 \\
4.296\end{array}$ & $\begin{array}{l}1.147 \\
1.109\end{array}$ & 0.617 & 0.5471 \\
\hline $\begin{array}{l}\text { Control (Pre-test) } \\
\text { Control (Post-test) }\end{array}$ & $\begin{array}{l}15 \\
15\end{array}$ & $\begin{array}{l}74.926 \\
74.960\end{array}$ & $\begin{array}{l}4.799 \\
4.682\end{array}$ & $\begin{array}{l}1.239 \\
1.208\end{array}$ & 0.289 & 0.7768 \\
\hline \multicolumn{7}{|c|}{ Triglycerides (TG) } \\
\hline $\begin{array}{c}\text { Experiment (Pre-test) } \\
\text { Experimental (Post-test) }\end{array}$ & $\begin{array}{l}15 \\
15\end{array}$ & $\begin{array}{l}135.473 \\
217.626\end{array}$ & $\begin{array}{c}9.647 \\
314.503\end{array}$ & $\begin{array}{c}2.491 \\
81.204\end{array}$ & 1.011 & 0.3292 \\
\hline $\begin{array}{l}\text { Control (Pre-test) } \\
\text { Control (Post-test) }\end{array}$ & $\begin{array}{l}15 \\
15\end{array}$ & $\begin{array}{l}132.913 \\
133.113\end{array}$ & $\begin{array}{l}14.755 \\
15.297\end{array}$ & $\begin{array}{l}3.809 \\
3.949\end{array}$ & 0.617 & 0.5471 \\
\hline
\end{tabular}


Mean and Standard Deviation values of Hemoglobin $(\mathrm{Hb})$ of pre-test and post-test of experimental group was $12.780 \pm 0.421$ and $12.913 \pm 0.456$ respectively. However, the Mean and Standard Deviation values of Hemoglobin $(\mathrm{Hb})$ of pre-test and post-test of control group were $12.473 \pm 0.240$ and $12.506 \pm 0.265$. The t-value in case of experimental group was 1.740 and for control group it was 0.517 as show in the Figure 4.

No significant between-group differences were noted in Haemoglobin $(\mathrm{Hb})$ since the calculated value of $(\mathrm{t}=$ 1.740 ) is smaller than tabulated value of $t_{0.05}(14)=2.1448$ for the selected degree of freedom and level of significance. The data does suggest that the differences between pre-test and post-test of Hemoglobin ( $\mathrm{Hb})$ in experimental and control group are insignificant. The t-test and p-value for the Experimental (Pre-Test \& Post-Test) and Control (Pre-Test \& Post-Test) Groups on the parameter Hemoglobin $(\mathrm{Hb})$ has been presented graphically in Figure 5.

\subsection{Total Cholesterol (TC)}

A glance at Table 3 shows the Mean and Standard Deviation values of Total Cholesterol (TC) of pre-test and post-test of experimental group was $167.240 \pm 14.598$ and $168.940 \pm 15.355$ respectively. However, the Mean and Standard Deviation values of Total Cholesterol (TC) of pre-test and post-test of control group were $166.760 \pm$ 14.613 and $166.893 \pm 14.266$. The $t$-value in case of experimental group was 1.937 and for control group it was 0.581 as show in the Figure 4.

No significant between-group differences were noted in Total Cholesterol (TC) since the calculated value of $(t=1.937)$ is smaller than tabulated value of $t_{0.05}(14)=2.1448$ for the selected degree of freedom and level of significance. The data does suggest that the differences between pre-test and post-test of Total Cholesterol (TC) in experimental and control group are insignificant. The t-test and p-value for the Experimental (Pre-Test \& Post-Test) and Control (Pre-Test \& Post-Test) Groups on the parameter Total Cholesterol (TC) has been presented graphically in Figure 6.

\subsection{Low Density Lipoprotein Cholesterol (LDL-Cholesterol)}

A glance at Table 3 shows the Mean and Standard Deviation values of Low Density Lipoprotein Cholesterol

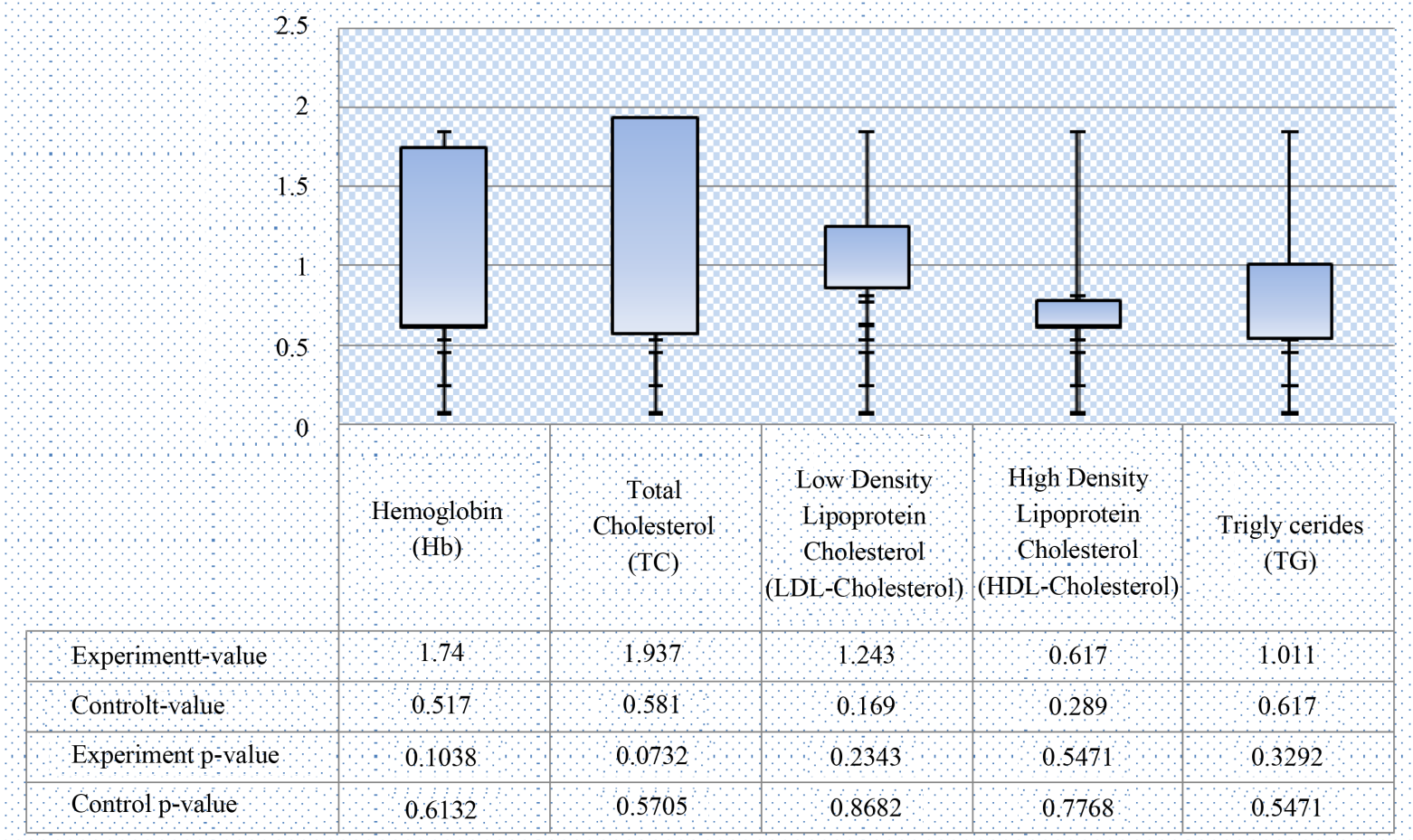

Figure 4. t-value and $p$-value for the experimental (Pre-Test \& Post-Test) and control (Pre-Test \& Post-Test) groups scores of hematological parameter. 

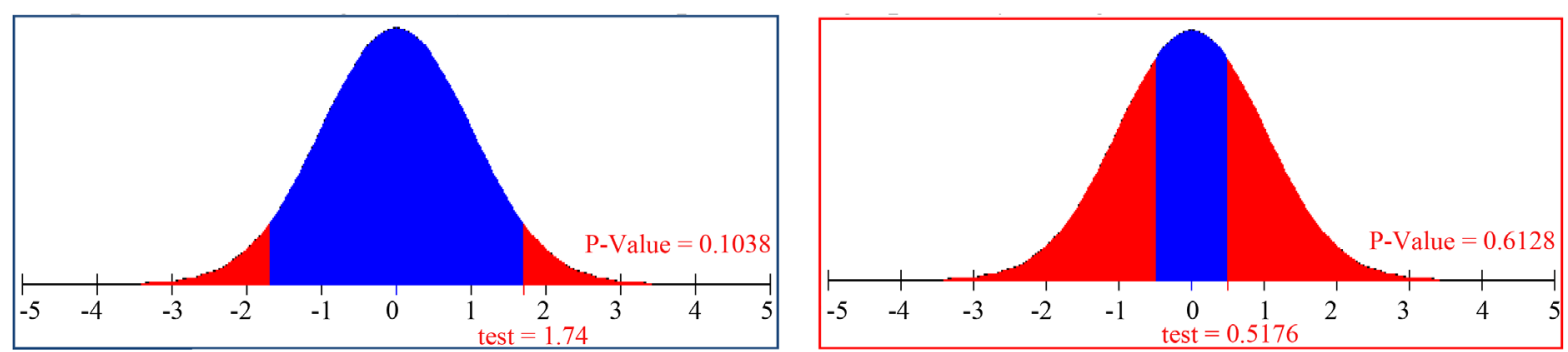

Figure 5. t-test and $p$-value for the experimental (Pre-Test \& Post-Test) and control (Pre-Test \& Post-Test) groups on the parameter hemoglobin $(\mathrm{Hb})$.

(LDL-Cholesterol) of pre-test and post-test of experimental group was $119.120 \pm 7.640$ and $119.486 \pm 7.694$ respectively. However, the Mean and Standard Deviation values of Low Density Lipoprotein Cholesterol (LDLCholesterol) of pre-test and post-test of control group were $118.980 \pm 7.506$ and $119.040 \pm 7.532$. The t-value in case of experimental group was 1.243 and for control group it was 0.169 as show in the Figure 4.

No significant between-group differences were noted in Low Density Lipoprotein Cholesterol (LDL-Cholesterol) since the calculated value of $(t=1.243)$ is smaller than tabulated value of $t_{0.05}(14)=2.1448$ for the selected degree of freedom and level of significance. The data does suggest that the differences between pre-test and post-test of in Low Density Lipoprotein Cholesterol (LDL-Cholesterol) in experimental and control group are insignificant. The t-test and p-value for the Experimental (Pre-Test \& Post-Test) and Control (Pre-Test \& Post-Test) Groups on the parameter Low Density Lipoprotein Cholesterol (LDL-Cholesterol) has been presented graphically in Figure 7.

\subsection{High Density Lipoprotein Cholesterol (HDL-Cholesterol)}

A glance at Table 3 shows the Mean and Standard Deviation values of High Density Lipoprotein Cholesterol (HDL-Cholesterol) of pre-test and post-test of experimental group was 75.120 \pm 4.443 and $75.206 \pm 4.296$ respectively. However, the Mean and Standard Deviation values of High Density Lipoprotein Cholesterol (HDLCholesterol) of pre-test and post-test of control group were $74.926 \pm 4.799$ and $74.960 \pm 4.682$. The t-value in case of experimental group was 0.617 and for control group it was 0.289 as show in the Figure 4.

No significant between-group differences were noted in High Density Lipoprotein Cholesterol (HDL-Cholesterol) since the calculated value of $(t=0.617)$ is smaller than tabulated value of $t_{0.05}(14)=2.1448$ for the selected degree of freedom and level of significance. The data does suggest that the differences between pre-test and post-test of High Density Lipoprotein Cholesterol (HDL-Cholesterol) in experimental and control group are insignificant. The t-test and p-value for the Experimental (Pre-Test \& Post-Test) and Control (Pre-Test \& PostTest) Groups on the parameter High Density Lipoprotein Cholesterol (HDL-Cholesterol) has been presented graphically in Figure 8.

\subsection{Triglycerides (TG)}

A glance at Table 3 shows the Mean and Standard Deviation values of Triglycerides (TG) of pre-test and post-test of experimental group was $135.473 \pm 9.647$ and $217.626 \pm 314.503$ respectively. However, the Mean and Standard Deviation values of Triglycerides (TG) of pre-test and post-test of control group were $132.913 \pm$ 14.755 and $133.113 \pm 15.297$. The t-value in case of experimental group was 1.011 and for control group it was 0.617 as show in the Figure 4.

No significant between-group differences were noted in Triglycerides (TG) since the calculated value of $(\mathrm{t}=$ 1.011 ) is smaller than tabulated value of $t_{0.05}(14)=2.1448$ for the selected degree of freedom and level of significance. The data does suggest that the differences between pre-test and post-test of Triglycerides (TG) in experimental and control group are insignificant. The t-test and p-value for the Experimental (Pre-Test \& Post-Test) and Control (Pre-Test \& Post-Test) Groups on the parameter Triglycerides (TG) has been presented graphically in Figure 9.

\section{Conclusion}

In summary, the present work manifests an overriding endeavor to explore effects of Chandra nadi pranayama on hematological parameters of university level girls. No significant differences were found in Hemoglobin (Hb), 

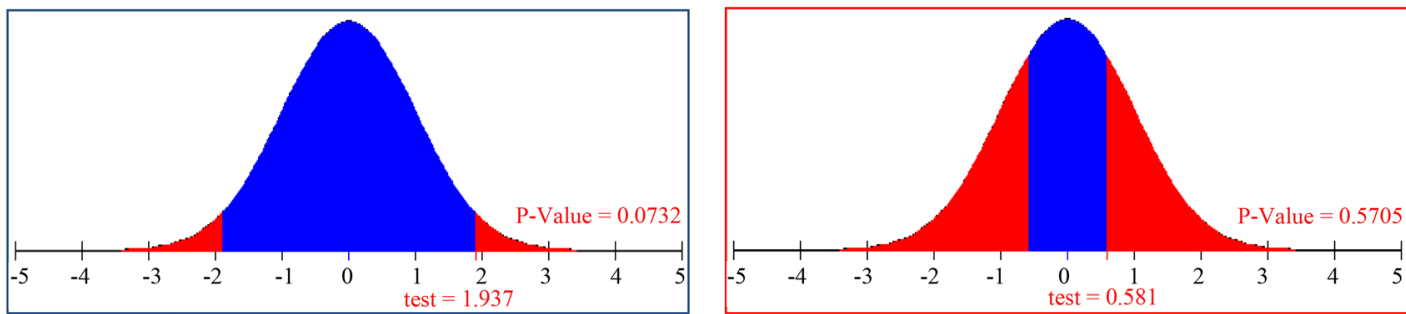

Figure 6. t-test and $p$-value for the experimental (Pre-Test \& Post-Test) and control (Pre-Test \& Post-Test) groups on the parameter total cholesterol (TC).
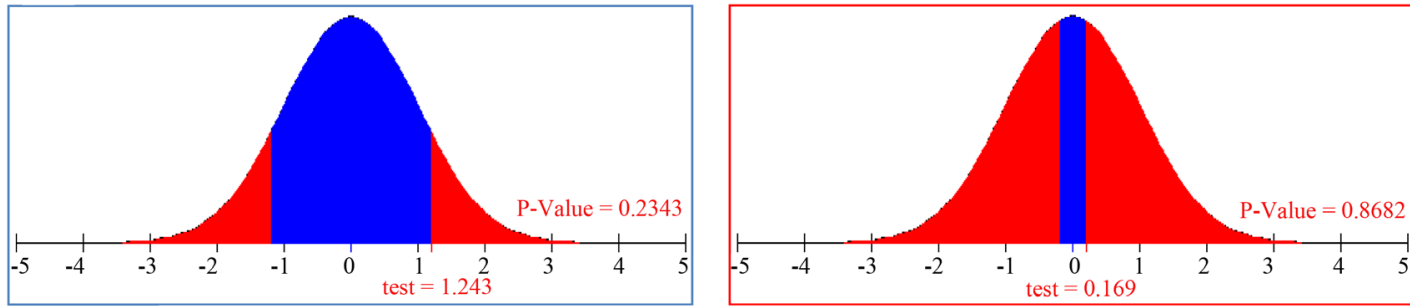

Figure 7. t-test and p-value for the experimental (Pre-Test \& Post-Test) and control (Pre-Test \& Post-Test) groups on the parameter low density lipoprotein cholesterol (LDL-cholesterol).
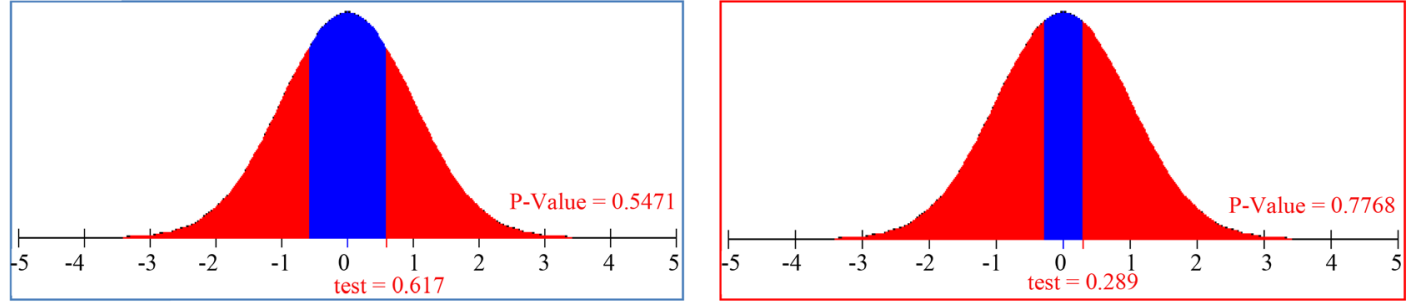

Figure 8. t-test and $p$-value for the experimental (Pre-Test \& Post-Test) and control (Pre-Test \& Post-Test) groups on the parameter high density lipoprotein cholesterol (HDL-cholesterol).
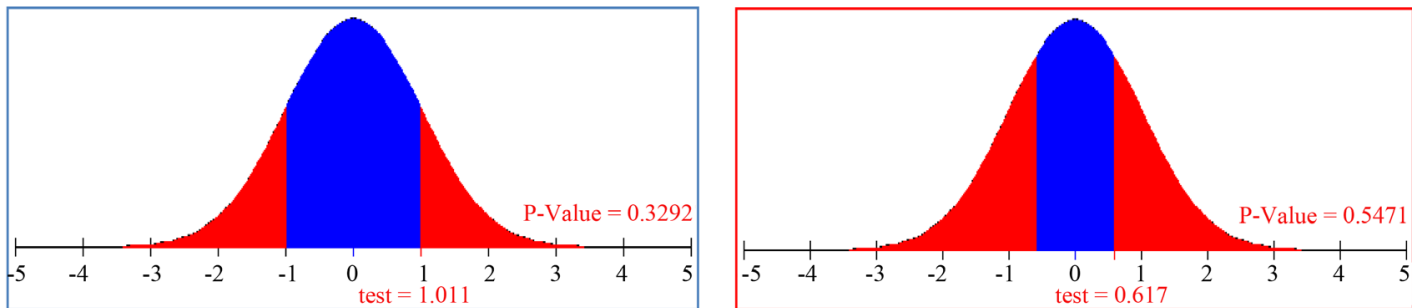

Figure 9. t-test and $p$-value for the experimental (Pre-Test \& Post-Test) and control (Pre-Test \& Post-Test) groups on the parameter triglycerides (TG).

Total Cholesterol (TC), Low Density Lipoprotein Cholesterol (LDL-Cholesterol), High Density Lipoprotein Cholesterol (HDL-Cholesterol) and Triglycerides (TG) of university level girls.

\section{Acknowledgements}

A special acknowledgement of appreciation for this work in preparing the original manuscript is due to assistance from University Grants Commission (U.G.C.) New Delhi in regards to the sanction of M.R.P (Minor and Major) Research Projects.

\section{References}

Gitananda, S. (2008). Pranayama: The Fourth Limb of Ashtanga Yoga. Pondicherry: Satya Press. 
Jastrzębska, M., Foltyńska, A., Torbus-Lisiecka, B., Chelstowski, K., Pieczul-Mróz, J., \& Klimek, K. (2002). Fibrinogen and von Willebrand Factor Levels in Relation to Lipid Profile and Blood Pressure in Children Whose Fathers Have a History of Premature Myocardial Infraction. Polish Heart Journal, 56, 488-495.

Krisanaprakornkit, T., Krisanaprakornkit, W., \& Pivavahatkul, N. (2006). Meditation Therapy for Anxiety Disorders. Cochrane Database of Systematic Reviews, 25, Article ID: CD004998. http://dx.doi.org/10.1002/14651858.CD004998.pub2

Kumar, K. Y. (2005). Achieve Inner Well-Being through Practice of Yoga. The Times of India, 14.

Maharishi, M. Y. (1972). The Science and Art of Living. Los Angeles. New York: International SRM Publications.

Michalsen, A., Grossman, P., \& Acil, A. (2005). Rapid Stress Reduction and Anxiolysis among Distressed Women as a Consequence of a Three-Month Intensive Yoga Program. Medical Science Monitor, 11, 555-561.

Nagendra, H. R., \& Nagarathna, R. (1977). New Perspective in Stress Management. Bangalore: Vivekananda Kendra Parkashana.

Smith, C., Hancock, H., \& Blake-Mortimer, J. (2007). A Randomised Comparative Trial of Yoga and Relaxation to Reduce Stress and Anxiety. Complementary Therapies in Medicine, 15, 77-83. http://dx.doi.org/10.1016/j.ctim.2006.05.001

Tamini, L. K. (1961). The Science of Yoga. Madras: The Theosophical Publishing House.

Telles, S., Reddy, S. K., \& Nagendra, H. R. (2000). Oxygen Consumption and Respiration Following Two Yoga Relaxation Techniques. Applied Psychophysiology and Biofeedback, 25, 221-227. http://dx.doi.org/10.1023/A:1026454804927 